(RESEARCH ARTICLE)

\title{
Evaluation of agronomic characters of finger millet (Eleusine coracana ( $L$ ) Gaertn) as influenced by poultry manure in the Northern Guinea Savanna agroecology, Nigeria
}

\author{
Garjila Yakubu Ali 1, ${ }^{*}$, Shiyam John Okokoh ${ }^{2}$ and Bukar Nuhu ${ }^{1}$ \\ ${ }^{1}$ Department of Agronomy, Faculty of Agriculture, Federal University Kashere, P.M.B 0182 Gombe, Gombe State, Nigeria. \\ 2 Department of Crop Science, Faculty of Agriculture, Forestry and Wildlife Resources Management, University of Calabar, \\ P.M.B 1115 Calabar, Cross River State, Nigeria.
}

Publication history: Received on 28 August 2019; revised on 21 September 2019; accepted on 23 September 2019

Article DOI: https://doi.org/10.30574/wjarr.2019.3.3.0056

\begin{abstract}
A field experiment was conducted at the Teaching and Research Farm, Taraba State College of Agriculture Jalingo in 2017 to evaluate the effect of poultry manure on agronomic parameters of finger millet. The treatments evaluated were poultry manure compost at $0,2,4,6$ and $8 \mathrm{t} / \mathrm{ha}$. The treatments were replicated three times and arranged in a randomized complete block design (RCBD). The results obtained showed that finger millet responded positively to poultry manure treatment in all agronomic parameters evaluated with the best values obtained at $8 \mathrm{t}$ poultry manure/ha. Finger millet plants in this treatment were tallest $(45.20 \mathrm{~cm})$, with highest number of tillers/plant (7.90), highest LAI (52.19), as well as lowest number of days to $50 \%$ flowering (103.13), highest number of spikes/plant (18.09), longest spikes $(4.65 \mathrm{~cm})$ and highest grain yield $(3.04 \mathrm{t} / \mathrm{ha})$. This performance trend indicates that the best agronomic parameters could be obtained for finger millet by applying $8 \mathrm{t}$ poultry manure/ha or more in the study area.
\end{abstract}

Keywords: Agronomic characters; Finger millet; Northern Guinea Savanna; Poultry manure; Nigeria.

\section{Introduction}

Fingers millet (Eleusine coracana (L) Gaertn) is a cereal grass grown for its grain. It is a robust tofted, tillerring annual grass up to $170 \mathrm{~cm}$ high. The inflorescence is a panicle with 4-19 finger-like spikes that resemble a first when mature hence the name finger millet [1]. It is one of the most important staple food cereals in Sub-Sahara Africa and in many countries in South Asia [2]. The crop is considered to be Indigenous to the highland areas of Uganda and Ethiopia and is majorly produced and locally consumed by the resource-poor farming households (3). Comparatively finger millet grains are considered nutritionally superior having contained more amounts of minerals such as calcium as well as essential amino acids than most other food grains [2].The grain is readily digestible and serve as a staple food, weaning food, or a cash crop which provides income generating opportunities. The sprouted grains are used to make liquor and beer and the byproducts used for livestock feeding [4].

Though a minor millet compared with pearl millet, finger millet has potential for food security and economic growth in dryl and areas where frequent crop failures and acute food shortages are phenomenal [5, 6]. The crop is well adapted and performs better than other food cereals in agronomically marginal areas and the grains have excellent storage quality even under poor storage conditions [7].

Finger millet is an orphan crop and research work to provide the necessary agronomic information for enhanced productivity of the crop is still scanty. The crop is cultivated by peasant farmers in most parts of Africa including Nigeria and average yield of the crop remain as low as $1 \mathrm{t} /$ ha which is below the potential compared with the yield of 5-6 t/ha obtained in other parts of the world like in Kenya and India [2, 6, 8].

\footnotetext{
${ }^{*}$ Corresponding author

E-mail address: ygarjila@yahoo.com
} 
Soil degradation and soil moisture deficits are among the major determinants of declining agricultural productivity commonly encountered in dry and farming especially in intensive cultivation. Continuous cultivation and heavy application of synthetic fertilizers degrades the soil rapidly and is detrimental to soil health and soil productivity. This practice is not suitable for fragile soils or arid ecologies where finger millet is grown commercially. Adoption of low inputs sustainable farming systems such as organic farming can guarantee soil fertility maintenance for enhanced crop yield under the zero inputs traditional cropping systems. Organic agriculture prohibits the use of synthetic farm inputs and relies on practices such as application of organic manures, organic mulches, crop rotations, etc to manage soil fertility. The appropriate quantity of organic manure to be applied for effectiveness depends on the nutrient content of the material, the soil fertility status and the nutrient requirement of the crop. Such investigations have not been carried out on finger millet in the study area. Poultry manure is commonly used as a substitute for inorganic fertilizers which are scarce and expensive but information on poultry manure requirement of finger millet in the study area is still lacking and the objective of this trial was to bridge this research gap.

\section{Material and methods}

The experiment was conducted in 2017 at the Teaching and Research Farm of the Taraba State College of Agriculture, Jalingo (Latitude $8^{0} 89^{\prime} \mathrm{N}$ and Longitude $11^{0} 36^{\prime} \mathrm{E}$ ). The area are enjoys average annual rainfall of $700-1000 \mathrm{~mm}$ distributed over seven months from April/May to October/November and at elevation 349 meters above sea level [9].

The land was cleared manually with machete, fine tilled manually and seedbeds of $2 \mathrm{~m} \times 3 \mathrm{~m}\left(6.0 \mathrm{~m}^{2}\right)$ made with hand hoe. The plots were demarcated by $1.0 \mathrm{~m}$ wide pathways and arranged in three blocks spaced $1.5 \mathrm{~m}$ apart each containing five unit plots. The treatments were five poultry manure $(\mathrm{pm})$ rates viz; $0,2,4,6$ and $8 \mathrm{t} / \mathrm{ha}$ each replicated three times and laid out in a randomized complete block design (RCBD).

The seeds of finger millet sourced from farmers' seed banks in Jalingo were sown by drilling and later thinned to one plant per stand spaced $20 \mathrm{~cm}$ x $50 \mathrm{~cm}$ three weeks after sowing (WAS). The poultry manure sourced from the college poultry farm was well composted under shade for four weeks before being incorporated into the soil two weeks before planting.

Weeding was done manually at three and six weeks after planting using a hand hoe. Data collected on five randomly tagged plants used for sampling were plant height, number of tillers, leaf area index, days to $50 \%$ flowering number of spikes, spike length and grain yield. Leaf area index was determined at 8 WAS using the formula as reported by [10].

Growth and yield data collected were subjected to analysis of variance (ANOVA) using statix 10.0 software and significant means were compared using Turkey's 1 degree of freedom test for nonadditivity (TDT).

\section{Results and discussion}

The poultry manure analyzed showed that it contained adequate levels of nutrients and organic matter (Table 1) and their regular use on farm land improves and sustains the quality of soil in the long run.

The finger millet tested responded to poultry manure application in all agronomic parameters assessed (Table 2). Plant height different significantly at Turkey is 1 degree of freedom test at each poultry manure (PM) rate and was height in finger millet plants fertilized with the highest PM rate $(8 \mathrm{t} / \mathrm{ka})$, while shortest plants were recorded in the control plots. Highest number of tillers per plant (7.00) were recorded on plants treated with 8t PM/ha followed by 6-8t pm/ha, while lowest number of tillers were recorded for the control plots. Also LAI were highest $(52.19 \mathrm{~cm})$ plants treated with $8 \mathrm{t}$ $\mathrm{PM} / \mathrm{ha}$, while lowest values were recorded for the control plants.

Finger millet plants treated with $8 \mathrm{t}$ pm/ha attained 50\% flowering earlier (103.13 days) than the other treatments. Both number and length of spikes were influenced by pm application to finger millet highest and longer spikes were observed in plants that received $8 \mathrm{t} \mathrm{pm} /$ ha $(18.09$ and $4.65 \mathrm{~cm}$ ) respectively (Table 2 ) than those in other fertilizer rates and the control plants. Grain yield followed a trend similar to that of number and length of spikes with the highest yield produced at $8 \mathrm{t} \mathrm{pm/ha} \mathrm{(3.04)} \mathrm{which} \mathrm{is} \mathrm{in} \mathrm{agreement} \mathrm{with} \mathrm{the} \mathrm{findings} \mathrm{of} \mathrm{[12]} \mathrm{who} \mathrm{reported} \mathrm{similar} \mathrm{highest} \mathrm{grain} \mathrm{yield}$ with increase in organic manure application. While lowest yield figure was recorded in zero fertilizer plots. 
Table 1 Some chemical properties of poultry manure used in the experiment.

\begin{tabular}{ll}
\hline Soil parameter & Value \\
\hline $\mathrm{pH}$ & 7.2 \\
$\mathrm{~N} \mathrm{( \% )}$ & 2.42 \\
$\mathrm{NH} 4+(\%)$ & 0.14 \\
$\mathrm{~K} 20(\%)$ & 1.70 \\
$\mathrm{Ca}$ & 3.64 \\
$\mathrm{Mg}$ & 2.18 \\
$\mathrm{Mn}$ & 0.04 \\
Org. C (\%) & 36.3 \\
Organic matter & 62.2 \\
C/N Ratio & 14.5 \\
\hline
\end{tabular}

Table 2 Growth and yield parameters of finger millet as influenced by poultry manure rate in Northern Guinea Savanna, Nigeria

\begin{tabular}{cccccccc}
\hline $\begin{array}{c}\text { Manure } \\
\text { rate (t/ha) }\end{array}$ & PH & TP & LAI & DF50 & SPP & SL & $\begin{array}{c}\text { Grain yield } \\
\text { (t/ha) }\end{array}$ \\
\hline 0 & $22.49 \mathrm{e}$ & $2.70 \mathrm{e}$ & $36.12 \mathrm{e}$ & $112.23 \mathrm{e}$ & $5.28 \mathrm{e}$ & $3.40 \mathrm{e}$ & $2.45 \mathrm{e}$ \\
2 & $29.82 \mathrm{~d}$ & $3.51 \mathrm{~d}$ & $40.15 \mathrm{~d}$ & $109.25 \mathrm{~d}$ & $9.15 \mathrm{~d}$ & $4.11 \mathrm{~d}$ & $2.75 \mathrm{~d}$ \\
4 & $37.34 \mathrm{c}$ & $5.26 \mathrm{c}$ & $46.33 \mathrm{c}$ & $107.19 \mathrm{c}$ & $12.13 \mathrm{c}$ & $4.19 \mathrm{c}$ & $2.83 \mathrm{c}$ \\
6 & $38.17 \mathrm{~b}$ & $6.27 \mathrm{~b}$ & $49.17 \mathrm{~b}$ & $105.19 \mathrm{~b}$ & $16.11 \mathrm{~b}$ & $4.52 \mathrm{~b}$ & $2.91 \mathrm{~b}$ \\
8 & $45.20 \mathrm{a}$ & $7.90 \mathrm{a}$ & $52.19 \mathrm{a}$ & $103.13 \mathrm{a}$ & $18.09 \mathrm{a}$ & $4.65 \mathrm{a}$ & $3.04 \mathrm{a}$ \\
SE & 0.014 & 0.049 & 2.850 & 0.013 & 0.014 & 0.021 & 0.086 \\
F-cal & $*$ & $*$ & $*$ & $*$ & $*$ & $*$ & $*$ \\
\hline
\end{tabular}

Mean with different alphabetic in the same column are significantly different at p.05 by LSD, ${ }^{*}=$ significant.

\section{Conclusion}

Finger millet growth and grain yield indices were maximized at the highest fertilizer rate indicating that further yield improvement could still be obtained at rates higher than $8 \mathrm{t} \mathrm{mm} / \mathrm{ha}$. However farmers in Northern Guinea Savanna agroecological zone of Nigeria could adopt this fertilizer rate to maximize finger millet yield, while further trials using higher fertilizer rates are recommended to ascertain the best fertilizer rate for optimum performance of this crop.

\section{Compliance with ethical standards}

\section{Acknowledgments}

There are no acknowledgements to make

\section{Disclosure of conflict of interest}

There is no conflict of interest whatsoever among the authors to disclose. 


\section{References}

[1] FAO (2012). Semi or Scientist Division of Agronomy. The Agronomy of Kharif Crops, 3(8), 231-233.

[2] Wafula WN, Nicholas KK, Henry OF, Siambi M and Gweyi-Onyango JP. (2016). Finger millet (Eleusine coracana L.) grain yield and yield components as influenced by phosphorus application and variety in Western Kenya. International Journal of Tropical Plant Research, 3(3), 673 - 680.

[3] Adugna A, Tesso T, Degu E, Tadesse T, Merga F, Legesse W, Tirfessa A, Kidane H, Wole A and Daba C. (2011). Genotype-by-enviroment interaction and yield stability analysis in finger millet (Eleusine coracana L. Gaertn) in Ethiopia..American Journal of Plant Sciences, 2, 408 - 415.

[4] Raj KA. (2012). Economic of finger millet (Eleusine coracana G.) production and marketing in peri-urban area of Pokhara Valley of Nepal. Journal of Development and Agricultural Economics, 4(6), 151 - 157.

[5] Okalebo JR, Jutto PM and Gathera KW. (1991). Effect of form and method of phosphate fertilizer application on maize, sorghum and millet growth in semi-arid environment of Kenya II: Effect of bulrush and finger millet. East African Forestry Journal, 55, 239 - 248.

[6] NRC. (National Research Council). (1996). Lost crops of Africa: Grains. National Academy Press, Washington D. C. 39 - 57.

[7] Henao J and Baanante C. (2006). Agricultural production and soil nutrient mining in Africa: Implication for resource conservation and policy development. Technical Bulletin.

[8] Oduori COA. (2005). The importance and research status of finger millet in Africa. A Paper Presented at the McKnight Foundation Collaborative Crop Research Program Workshop on Tef \& Finger Millet: Comparative Genomics of the Chloridoid Cereals at the Biosciences for East and Central Africa (BECA) ILRI, Nairobi, Kenya, 28-30, 12.

[9] Abuzar MR, Sadozai, GU, Baloch MS, Shah AA, Javaid IH and Hussain T. (2011). Effect of plant Population densities of yield of maize. Journal of Animal and plant science, 21(4), 692 - 695.

[10] Tsado EK, Jatau DB and Daniya E. (2016). Performance of finger millet (Eleusine coracana L. Gaertn) as influence by nutrient source in the Sourthern and Northern Guinea Savannah, Nigeria. Direct Research Journal of Agriculture and Food Science, 4(7), 182-192.

\section{How to cite this article}

Garjila YA, Shiyam JO and Bukar N. (2019). Evaluation of agronomic characters of finger millet (Eleusine coracana (L) Gaertn) as influenced by poultry manure in the Northern Guinea Savanna agroecology, Nigeria. World Journal of Advanced Research and Reviews, 3(3), 54-57. 